\title{
The Effect of Student Worksheets Through the Edmodo Network on Concept Understanding and Independent Learning on Hydrocarbon Materials
}

\author{
Khairini $^{1^{*}}$, Ibnu Khaldun${ }^{1}$, Andi Ulfa Tenri Pada ${ }^{1}$ \\ ${ }^{1}$ Science Education Study Program, Postgraduate Program, Syiah Kuala University, Banda Aceh, Indonesia
}

DOI: $10.29303 /$ jppipa.v7i3.701

\section{Article Info}

Received: March 29th 2021

Revised: July $2^{\text {th }}, 2021$

Accepted: July $12^{\text {th }}, 2021$

\begin{abstract}
This study aims to determine the effect of student worksheets through the Edmodo network on understanding concepts and learning independence on hydrocarbon material. The research method used is an experiment with a quantitative approach. The research design used was a pretest-posttest control group design. The population of this study was students of class XI SMAN 5 Banda Aceh with data collection techniques by random sampling to obtain two classes that became the research sample. The research instruments used were reasoned test questions and questionnaires. Based on the results of the t-test analysis of conceptual understanding with a significant score of $0.015<0.05$, it shows that there is a significant difference between the control class and the experimental class. The results of the t-test of students' learning independence showed that the significant score was $0.000<0.05$, which means that the data had a significant difference between the control and experimental classes. The conclusion in this study is that student worksheets through the Edmodo network can affect students' understanding of concepts and learning independence. This research concludes that using student worksheets through the Edmodo network in chemistry learning is more effective in increasing understanding of concepts and students' learning independence for the better.
\end{abstract}

Keywords: Student worksheet; Edmodo; Concept Understanding; Independent Learning; covid-19.

Citation: Khairini, K., Khaldun, I., \& Pada, A. (2021). The Effect of Student Worksheets Through the Edmodo Network on Concept Understanding and Independent Learning on Hydrocarbon Materials. Jurnal Penelitian Pendidikan IPA, 7(3), 429-436. doi:https://doi.org/10.29303/ippipa.v7i3.701

\section{Introduction}

Chemistry learning in high school contains many concepts that are quite difficult and complicated for students to understand, because it involves chemical reactions and calculations and involves abstract concepts so that students need a deep understanding of concepts so that students do not have to rely on teachers (Ristiyani and Bahriah, 2016; Uce \& Ceyhan, 2019; Khairunnisak, 2018; Susilawati et al., (2021).

One of the chemical materials that need a deep conceptual understanding is hydrocarbon material because it is classified as material that is difficult for students to understand (Pertiwi \& Masykuri, 2017;
Fakhrurrazi, et al., 2017). Mushuri et al, (2015) also say that understanding concepts that are misunderstood by students will result in students having a wrong understanding, which is said to understand the concept, namely if the concept has been stored in the minds of students so that students can make examples of a concept and distinguish examples from nonexamples.

The difficulties experienced by students in understanding a learning material can lead to an inappropriate understanding of concepts (Muntholib, et al., 2018). Good concept understanding is the basis of good problem-solving skills (Kurniawan et al., 2016; Ulya, 2016; Kurniawan and Taqwa, 2018). This can be 
known based on research on understanding concepts that have been studied related to hydrocarbon materials (Wiqoyati, 2013).

Hydrocarbon material is very broad in scope and requires a long time to study. The length of time in learning results in students having to study outside the school environment. Based on these limitations, the internet was chosen as a way to make it easier for students to get information about the subject matter they need (Hermawan, et al, 2017).

This learning, it does not only focus on knowledge but also on learning activities in schools which are held to develop the attitudes, knowledge, and skills of students (Aulia et al., 2019). This is in accordance with the opinion of Fadhillah \& Faradina (2016), one of the attitudes that are expected to develop through the implementation of education is independence. Independence is the ability that a person has to do something and be responsible for it. According to Rikizaputra et al., (2021) independence is an important thing that must be developed in the learning process.

Based on the national exam scores of SMAN 5 Banda Aceh, the Chemistry UN data for the last three years from the 2017 academic year to 2019 are 35.63, 42.00, and 37.35. (Puspendik, 2017, 2018, 2019). The data shows that the UN scores of SMAN 5 Banda Aceh, especially on hydrocarbons, are relatively low and some students do not understand the concept of the material.

In the teaching and learning process, many obstacles are experienced such as the lack of time allocation, lack of understanding of students, and the unavailability of additional teaching materials so that the material is not conveyed properly, especially with the current situation, namely the Covid19 outbreak in the world. Almost all over the world face-to-face learning that is usually done in schools is disrupted. This problem is caused by the Corona Virus Disease (Covid19) which is not yet known when it will end, this has an impact on the education system in Indonesia (Dewi, 2020; Sadikin \& Hamidah, 2020; Rahmadani et al, 2021).

Learning activities in schools and universities must be carried out in their respective homes through available applications. The Ministry of Education and Culture issued Circular Letter Number 3 of 2020 concerning the prevention of COVID-19 in education units stating that schools and universities were closed (Kemendikbud RI, 2020). Therefore, this is the cause of learning that must be done independently, not only independently, students are also required to be able to understand the learning material. Learning independence is one of the important attitudes possessed by students (Aulia et al., 2019).
One of the efforts that can be made to improve learning independence and understanding of students' concepts is by providing learning tools to students in the teaching and learning process, namely in the form of Student Worksheets. One way that helps students to be more active in constructing their knowledge according to the guidance in the 2013 curriculum is by using student worksheets. This is supported by the statement of Prastowo (2014) Student worksheets are teaching materials that can reduce the teacher-centered paradigm to become student-centered so that students will be more active.

Based on the results of observations with students at SMAN 5 Banda Aceh, it shows that so far students are less interested in learning chemistry. The results of interviews with several chemistry teachers at SMAN 5 Banda Aceh, it is known that the value of learning chemistry, especially on the material peculiarities of the carbon atom and the nomenclature of hydrocarbon compounds is still relatively low. This can be seen from the average daily test score of students, which is 50.8. This value is low when compared to the minimum completeness criteria for chemistry lessons at the school, which is 75 . The level of completeness of students' daily tests based on the minimum completeness criteria ranges from $66 \%$, so it can be concluded that student learning outcomes in chemistry learning are not optimal.

The teacher at SMAN 5 Banda Aceh also explained that Student Worksheets are very necessary for learning Chemistry. However, so far the Student Worksheets used in schools are in the form of Student Worksheets containing descriptions, materials, and questions to strengthen certain concepts, but during the current COVID-19 pandemic, learning is required at home online. This will affect teaching and learning activities which are usually carried out face-to-face so that learning media is needed to facilitate students in the teaching and learning process. One solution is to use Edmodo learning media.

Edmodo is an interesting application for teachers and students that serves to share ideas, files, activity agendas, and assignments that can create teacher and student interactions, Edmodo also makes it easier for students and educators to communicate outside the classroom (Aulia et al., 2019). Edmodo provides a safe and easy way to build virtual classes based on class divisions like in a school. Through Edmodo, teachers and students can share notes and documents and can continue discussions online, Student Worksheets can also be given through the Edmodo network so as to create meaningful learning. Therefore, the researcher used the Student Worksheet through the Edmodo network. 
Several studies related to Edmodo have been carried out by several researchers (Aulia et al, 2019; Yakub et al, 2018; Kongchan, 2012) which state that learning using smartphone-based Edmodo can increase students' independence and learning motivation in a practical and effective manner so that they can be used by educators as a supporter in the learning process. Edmodo is designed very simply, providing space for teachers, students, and even parents to maximize the teaching and learning process. The results of research from Nurhayati et al., (2019) suggest that Edmodo is superior to the classroom because it uses e-learning which is supported by better usability and pedagogical usability, while Google Classroom is more suitable to be used as a complement to learning. Therefore, the authors are interested in conducting research on "The effect of student worksheets through the Edmodo network on understanding concepts and learning independence of students on hydrocarbon material at SMAN 5 Banda Aceh".

\section{Method}

This research was conducted using a quantitative approach. The design used is a pretest-posttest control group design. The population in this study were students of SMA Negeri 5 Banda Aceh class XI which consisted of 4 classes totaling 120 students, in the 2020/2021 school year. Sampling in this study was done by random sampling. All class XI was given a pretest to determine the initial state, then the results of the pretest were selected two classes that had values that were not much different or homogeneous, these two classes were used as the control class and the experimental class.

This research was conducted in the even semester of the 2020/2021 academic year. Before doing the lesson, the two classes were given a learning independence questionnaire and a pre-test. Then learning was carried out, where the experimental class used Student Worksheets via the Edmodo network while the control class used Student Worksheets via
WhatsApp. After carrying out the learning, both in the experimental class and the control class, a final test was carried out and the distribution of learning independence questionnaires. The difference in learning outcomes between the initial state and the final state is assumed to be the effect of the given treatment.

The data collection instrument used multiplechoice questions to measure the understanding of concepts and a questionnaire for the learning independence of students to measure the level of learning independence of students. Before using the data collection instrument, a validation test was carried out by experts. According to Yusrizal (2016) the validity of the test serves to determine the feasibility of the items in a test. In this study, the validity of the test was carried out in 2 stages, namely content validity and empirical validity. Furthermore, the instrument was tested on the class that had received the material. Based on the results of the trial, the validity, reliability, and item analysis processes were carried out, namely the level of difficulty and differentiating power.

\section{Result and Discussion}

\section{Concept Understanding Results}

The instrument to measure the understanding of the students' concepts in this study was a matter of pretest and posttest which had been validated first. Pretest and posttest scores were obtained after students answered 20 questions and their reasons. Salim and Haidir (2019) add that an instrument can be said to be valid if it can measure what the researcher wants and can reveal variable data appropriately. The results obtained were then tested using normality, homogeneity, and hypothesis testing (t-test) to see the improvement. Analysis of the results of learning understanding can be seen from the acquisition of pretest and posttest scores that have been given to students. Analysis of the initial ability of students' learning understanding can be seen in Table 1 .

Table 1. The average value of the results of the pretest learning understanding

\begin{tabular}{llllll}
\hline No & Class & Average & Normality $^{*}$ & Homogenity $^{* *}$ & Significance $^{* * *}$ \\
\hline 1 & Experiment & 26.67 & Sig: 0.129 & Sig: 0.554 & Sig (2-tailed) $0.279>0.05$ \\
& Control & 28.67 & Sig: 0.061 & & \\
\hline
\end{tabular}

Information

$*$ ) = Kolmogorov-Smirnov (Normal, sig. > 0.05)

$* *)=$ Levene Test (Homogeneous, Sig. $>0.005$ )

$* * *)$ = Idenpendent Sample t-Test (Significant, Sig. (2-tailed) $<0.05$

The results of the analysis in Table 1 show that the average score of the pretest value of the experimental class is 26.67 and the control class is 28.67 .
This shows that the data is normally distributed, namely $0.129>0.05$ in the experimental class and 0.061 in the control class. Meanwhile, the homogeneity test 
showed that the two classes had homogeneous data acquisition with an insignificant t-test, namely $0.279>$ 0.05 . Not significant between the pretest control and experimental classes. The results of the analysis of the posttest average value of students' conceptual understanding results can be seen in Table 2 .

Table 2. The average value of the posttest results of students' understanding of the concept

\begin{tabular}{llllll}
\hline No & Class & Average & Normality $^{*}$ & Homogenity $^{* *}$ & Significance \\
\hline 1 & Experiment & 85.50 & Sig: 0.192 & Sig: 0.055 & Sig (2-tailed) $0.015<0.05$ \\
2 & Control & 79.67 & Sig: 0.053 & & \\
\hline
\end{tabular}

Information

*) = Kolmogorov-Smirnov (Normal, sig. > 0.05)

$* *)=$ Levene Test (Homogeneous, Sig. $>0.005$ )

$* * *)$ ) Idenpendent Sample t-Test (Significant, Sig. (2-tailed) $<0.05$

Based on Table 2, it can be seen that the two classes are normally distributed, namely $0.129>0.05$ in the experimental class and $0.061>0.05$ in the control class. In addition to being normally distributed, the data for the two classes are also homogeneous, namely $0.055>0.05$. The results of the t-test analysis showed that the sig value was $0.015<0.05$, which means that the data showed a significant difference between the control class and the experimental class. The increase in the posttest average score in the experimental class was included in the category, namely 85.50 , and in the control class, namely 79.67. The comparison of the average score of the increase in the pretest and posttest scores can be seen in Figure 1.

This result shows that the average score of students' initial knowledge of hydrocarbon material is still low. After learning is done, there is an increase in the posttest score. The comparison of the average score of the increase in the pretest and posttest scores can be seen in Figure 1.

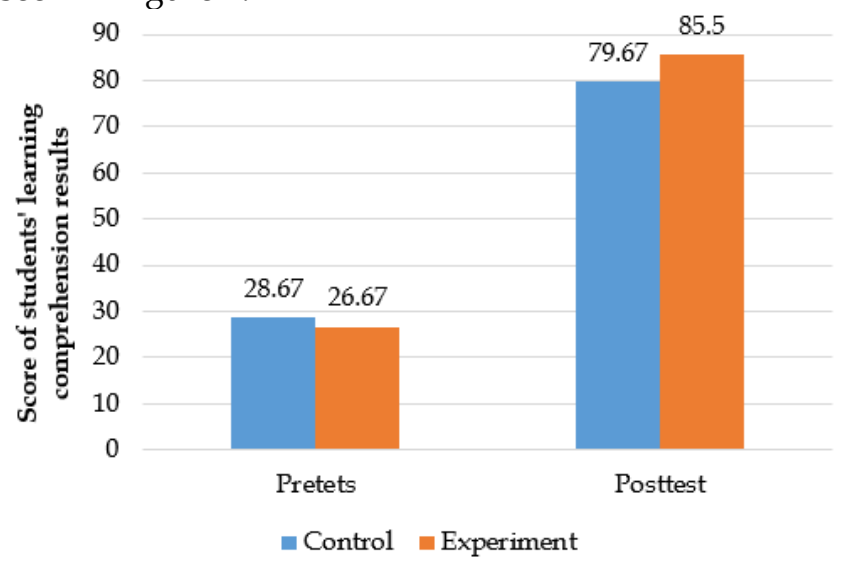

Figure 1. The value of understanding students' learning concepts

Based on the average score of learning comprehension results, it can be concluded that both classes experienced an increase in understanding, but the experimental class had a greater improvement than the control class. This increase indicates the important role of Student Worksheets through the Edmodo media network in achieving conceptual understanding and learning independence of students on hydrocarbon material. According to Uce \& Ceyhan (2019) learning chemistry contains concepts that are quite difficult and complicated to understand because it involves reactions, calculations, and abstract concepts so that students need a deep understanding of concepts. Pertiwi \& Masyuri (2017) also said that chemical materials, especially hydrocarbons, were classified as difficult materials for students to understand.

The teaching and learning process must also be carried out independently considering that it is currently the middle of the Covid-19 pandemic which causes learning to be disrupted and must be done online. According to Prastowo (2014), one of the efforts to improve the understanding of concepts and learning independence of students in the teaching and learning process is the Student Worksheet. Aulia et al., (2019) also argue that Edmodo media is very helpful for students in the online teaching and learning process because Edmodo provides a safe and easy way to build virtual classes based on class divisions like in school. Student Worksheets can also be provided via the Edmodo network.

The improvement that occurs proves that the teaching and learning process using Student Worksheets through the Edmodo network can make students' understanding of concepts and independence better. This statement is in accordance with the opinion (Aulia et al., 2019; Santoso., 2019; and Herowati., 2016) that Edmodo media is expected to be used properly so that teachers can improve students' understanding which is dynamic and effective because learning can be carried out anywhere and anytime. Edmodo media can increase the independence of students because teachers can upload presentations of teaching materials, give questions, put photos or videos, all of which can be downloaded by students and commented on, students can return at any time to repeat the material given, even homework can also be given via Edmodo.

According to Herowati (2016) students who collect their homework can be done using Edmodo, teachers can put the value of students' work to be a reference for students, Edmodo does not limit the 
number of virtual classes made by a teacher, teachers can put teaching materials to use. At the next level or school year, students can work together with other students in small groups formed by the teacher. When working on a project together they can put the necessary documents in the process, Edmodo allows teachers to put teaching materials that are very useful for students who are absent or unable to meet face-toface, quiet students can freely speak and express opinions without worrying about being embarrassed, while active children can post questions at any time as long as they are connected to the internet.

Edmodo was developed by Jeff O'Hara in 2008. Jeff O'Hara created Edmodo when he realized the need to create a friendly and safe educational environment where teachers and students can be actively involved in a holistic learning process. In 2010, a website was developed to provide a social collaboration experience between teachers and their students (Setyono, 2015; Naibi, et al, 2018; Mokhtar, 2018; Eguz, 2020).

\section{Independent Learning of Students}

The learning independence of students can be measured using a questionnaire (Aulia, et.al. 2019). The learning independence questionnaire was developed by Hidayati and Listyani (2010). The data from the analysis of the students' learning independence were first tested for normality and homogeneity and the $\mathrm{t}$ test. The analysis of the initial ability of independence in the control and experimental classes can be seen in Table 3.

Table 3. The average value of the pretest of learning independence

\begin{tabular}{|c|c|c|c|c|c|}
\hline No & Class & Avera-ge & Normality $^{*}$ & Homogenity & Significance $^{* \star \star *}$ \\
\hline 1 & Experiment & 40.5 & Sig: 0.130 & Sig: 0.293 & Sig (2-tailed) $0.386>0.05$ \\
\hline 2 & Control & 42.9 & Sig: 0.064 & & \\
\hline
\end{tabular}

Information

$\left.{ }^{*}\right) \quad=$ Kolmogorov-Smirnov (Normal, sig. > 0.05)

$* *)=$ Levene Test (Homogeneous, Sig. $>0.005$ )

$* * *)=$ Idenpendent Sample $\mathrm{t}$-Test (Significant, Sig. (2-tailed) $<0.05$

Based on Table 3, it is obtained that the average self-reliance pretest score in the experimental class is 40.5 and the control class is 42.9 which indicates that the ability of both classes is still low. The results of the normality test for the experimental class are $0.130>0.05$ and the control class $0.064>0.05$, which means the data is normally distributed. The results of the homogeneity test between the two classes are $0.293>0.05$, which means the data is homogeneous. The results of the t-test show that the sig value is $0.386>0.05$, this indicates that there is no significant difference between the pretest of independence of the control class and the experimental class, which means that the initial abilities of the experimental and control class students are the same. While the results of the posttest data analysis of the independence of the control and experimental classes can be seen in Table 4 .

Table 4. Average Posttest score of independence

\begin{tabular}{llllll}
\hline No & Class & Avera-ge & Normality $^{*}$ & Homogenity $^{* *}$ & Significance $^{* \star *}$ \\
\hline 1 & Experiment & 86.67 & Sig: 0.053 & Sig: 0.062 & Sig $(2$-tailed $) 0.000<0.05$ \\
2 & Control & 75.70 & Sig: 0.055 & & \\
\hline
\end{tabular}

Information

$\left.{ }^{*}\right) \quad=$ Kolmogorov-Smirnov (Normal, sig. > 0.05)

$* *)=$ Levene Test (Homogeneous, Sig. $>0.005)$

$* * *)$ = Idenpendent Sample t-Test (Significant, Sig. (2-tailed) $<0.05$

The results of the analysis in Table 4 obtained that the average self-reliance pretest score in the experimental class was 86.67 and the control class was 75.70 which indicated that the ability of both classes was still low. The results of the normality and homogeneity test of the experimental and control classes showed that the data were normally distributed and homogeneous because they had a sig value $>0.05$. The results of the t-test show that the sig value is 0.000 $<0.05$, which means that the data has a significant difference between the control and experimental classes.
The value of the independence of students in this study was seen from before and after treatment which aimed to determine the improvement that occurred during the learning process in the control and experimental classes. The results of the difference in the average independence of students can be seen in Figure 2. 


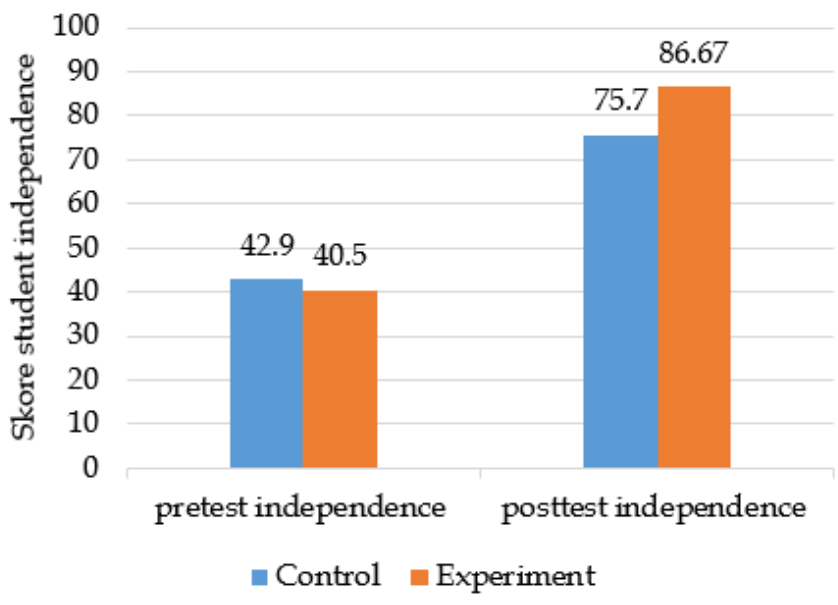

Figure 2. The value of students' independence

Based on Figure 2, it can be seen that the average score of students' independence before being given treatment in the control and experimental classes was 42.90 and 40.50 , both of which were still low, while the average score of the independence of students after treatment had increased. The average percentage of independence of students in the control class has increased to 75.70 while the results of the assessment of the average score of independence in the experimental class have become 86.67. The increase in learning independence that occurs in the experimental class indicates the effect of using Edmodo media in the teaching and learning process.

The use of Edmodo media is able to direct students to be directly involved in the learning process so that students can practice their learning independence. Safitri, (2017) said that the efforts made to train students' learning independence were through Edmodo media. Edmodo provides facilities for teachers and students with a safe place to communicate, collaborate, share learning content and applications, homework for students, discussions in virtual classes, online tests, and assessments.

\section{Conclusion}

Based on the results of research and discussion, it can be concluded that the effect of understanding the concept and independence of students by applying student worksheets through the Edmodo network is better on hydrocarbon material.

\section{Acknowledgments}

Thanks to all parties, namely validators, teacher facilitators, and others who have contributed to this research. Furthermore, to the students of class XI IPA1 and class XI IPA2 at SMA Negeri 5 Banda Aceh who have collaborated, thank you.

\section{References}

Aulia, L., Susilo, S., \& Subali, B. (2019). Upaya peningkatan kemandirian belajar siswa dengan model problem-based learning berbantuan media Edmodo. Jurnal Inovasi Pendidikan IPA, 5(1), 69-78. doi:https:// doi.org/10.21831/iipi.v5i1.18707. [Indonesian]

Dewi, W.A.F. (2020). Dampak covid-19 terhadap implementasi pembelajaran daring di sekolah. Edukatif: Jurnal Ilmu Pendidikan. 2 (1):55-61. doi: https://doi.org/10.31004/edukatif.v2i1.89 [Indonesian]

Eguz, E. (2020). Using Web 2.0 tools in and beyond the university classrooms: A case study of Edmodo. International Online Journal of Education and Teaching (IOJET), 7(3): 1205-1219. Retrieved from: https://eric.ed.gov/?id=EJ1258432

Fadhillah, N., \& Faradina, S. (2016). Hubungan kelekatan orang tua dengan kemandirian remaja SMA di Banda Aceh. Jurnal Ilmiah Mahasiswa Psikologi. 1(3):44-51. Retrieved from: http://jim.unsyiah.ac.id/Psikologi/article/view $\angle 1429$ [Indonesian]

Fakhrurrazi, M., Masykuri, M., \& Sarwanto. (2017). Analisis pembelajaran kimia pada materi hidrokarbon dan minyak bumi. Prosiding Seminar Nasional Pendidikan Sains, 167-171. [Indonesian]

Hermawan, B.A., Wonorahardjo, S., \& Marfuah, S. (2017). Efektifitas internet dalam learning cycle 6e pada materi hidrokarbon ditinjau dari hasil belajar siswa. Jurnal Kimia dan Pendidikan. 2(2):211-220.

doi:http://dx.doi.org/10.30870/educhemia.v2i2. $\underline{1800}$ [Indonesian]

Herowati. (2016). Kemandirian belajar siswa dalam online learning edmodo Di SMKN 1 Sumenep. Jurnal lentera sains. 6(2): 99-107. doi: https://doi.org/10.24929/lensa.v6i2.292 [Indonesian]

Hidayati, K \& Listyani, E. (2010). Improving instruments Of students' self-regulated learning. Jurnal Penelitian dan Evaluasi pendidikan. 14(1):83100.

Jamuri, Kosim, \& Doyan, A. (2015). Pengaruh Model Pembelajaran Kooperatif STAD BerbasisMultimedia Interaktif Terhadap Penguasaan Konsep Siswa pada Materi Termodinamika. Jurnal Penelitian Pendidikan IPA (JPPIPA), 1(1), 123-134. doi: https://doi.org/10.29303/ippipa.v1i1.11 [Indonesian] 
Kemdikbud RI, (2020). Surat Edaran Nomor 3 Tahun 2020 Tentang Pencegahan Corona Virus Disease (COVID-19). [Indonesian]

Khairunnisak. (2015). Peningkatan Pemahaman Konsepdan Motivasi Belajar Siswa Melalui Simulasi Physic Education Technology (PhET). Jurnal Penelitian Pendidikan IPA (JPPIPA), 4(1), 7-12.

https://doi.org/10.29303/jppipa.v4i2.109

[Indonesian]

Kurniawan, B.R., Handayanto, S.K., \& Parno. (2016). Profil Kemampuan Pemecahan Masalah Mahasiswa Fisika Universitas Negeri Malang, in: Inovasi Pembelajaran IPA Yang Bermakna dan Mencerdaskan. Presented at the Seminar Nasional Pendidikan IPA, Pascasarjana Universitas Negeri Malang, pp. 105-111. [Indonesian]

Kurniawan, B.R. \&Taqwa, M.R.A. (2018). Pengembangan Instrumen Tes Kemampuan Pemecahan Masalah Fisika pada Materi Listrik Dinamis. J. Pendidik. Teori Penelit. dan Pengemb. 3(11): 1451-1457. doi: http://dx.doi.org/10.17977/jptpp.v3i11.11761

[Indonesian]

Kongchan, C. (2012). How a non-digital-native teacher makes use of Edmodo. Retrieved from www.conference.pixel-online.netf.

Muntholib, Mayangsari, J., Pratiwi, Y.N., Muchson, Joharmawan, R., Yahmin, \& Rahayu, S. (2018). Development of simple multiple-choice diagnostic test of aced-base concept to identify students' alternative conceptions. Advances in Social Science, Education and Humanities Research. 218:251-268.

doi:

https://doi.org/10.2991/icomse-17.2018.45

Mokhtar, F. (2018). Breaking Barriers Through Edmodo: A Qualitative Approach on the Perceptions of University of Malaya Undergraduates. Online Learning, 22(1). doi:http://dx.doi.org/10.24059/olj.v22i1.1026.

Naibi, I.A., Jabri, M.A., \& Kalbani, I.A. (2018). Promoting students' paragraph writing using edmodo: an action research. TOJET: The Turkish Online Journal of Educational Technology, 17(1): 130-143. Retrieved from: https://eric.ed.gov/?id=EJ1165747

Nurhayati, D., Az-zahra, H, M., \& Herlambang, A, D. (2019). Evaluasi user pada edmodo dan google classroom menggunakan technique for user experience evaluation in e-lerning (TUXEL). Jurnal Pengembangan Teknologi Informasi dan Ilmu Computer. 3(4): 3771-3780. Retrieved from: https://j-ptiik.ub.ac.id/index.php/jptiik/article/view/5025 [Indonesian]
Pertiwi, Y., \& Masykuri, M. (2017). Penerapan TGTChempuzzle pada pembelajaran hidrokarbon untuk meningkatkan prestasi belajar kimia peserta didik. Jurnal Inovasi Pendidikan IPA, 3(1), 111-117.

doi:https://doi.org/10.21831/jipi.v3i1.11198

[Indonesian]

Puspendik. (2019). Laporan Hasil Ujian Nasional Tahun Pelajaran 2018-2019. Jakarta: Balitbang, Kemendikbud. [Indonesian]

Prastowo, A. (2014). Panduan kreatif membuat bahan ajar inovatif. Yogyakarta:Diva Press. [Indonesian]

Rahmadani, D., Chastanti, I., \& Harahap, D. (2021). Parents' Role in Biology Learning During the Covid 19 Pandemic. Jurnal Penelitian Pendidikan IPA, 7(2), 137-142. doi:https://doi.org/10.29303/jppipa.v7i2.583.

Rikizaputra, R., Lufri, L., Andromeda, A., \& Mufit, F. (2021). Analysis of Student Independence and Habits of Mind of Students in Biology Learning in Class X MIA through Portfolio Assessment. Jurnal Penelitian Pendidikan IPA, 7(2), 232-238. doi:https://doi.org/10.29303/jppipa.v7i2.630.

Ristiyani, E., \& Bahriah, E. (2016). Analisis Kesulitan Belajar Kimia Siswa di SMAN X Kota Tangerang Selatan. Jurnal Penelitian dan Pembelajaran IPA, 2(1), 18-29. doi:http://dx.doi.org/10.30870/jppi.v2i1.431. [Indonesian]

Sadikin, A., \& Hamidah, A. (2020). Pembelajaran daring di tengah wabah covid-19. BIODIK: Jurnal Ilmiah Pendidikan Biologi. 6(2): 214-224. doi: https://doi.org/10.22437/bio.v6i2.9759 [Indonesian]

Safitri, R., Oktaviani, D., \& Isnani, I. (2019). Validasi Lembar Kegiatan Peserta Didik dengan Pendekatan Inkuiri Berbantuan Geogebra. JIPMat, $4(2)$. doi:https://doi.org/10.26877/jipmat.v4i2.4216. [Indonesian]

Salim dan Haidir. (2019). Penelitian Pendidikan Metode, Pendekatan dan jenis. Jakarta: Kencana. [Indonesian]

Santoso, E. (2019). Kelas Virtual Menggunakan ELearning Berbasis Edmodo. Jurnal THEOREMS (The Original Research of Mathematics). 3(2):169177. [Indonesian]

Setyono, E.Y. (2015). Pengaruh penggunaan media jejaring sosial edmodo terhadap hasil belajar mahasiswa pada topik pembuatan kurva-s menggunakan microsoft excell. Soshum jurnal sosial dan humaniora, 5(1): 42-49. Retrieved from: http://ojs.pnb.ac.id/index.php/SOSHUM/articl e/view/226 [Indonesian] 
Susilawati, S., Doyan, A., Artayasa, P., Soeprianto, H., \& Harjono, A. (2020). Analysis of Validation Development Science Learning Tools using Guided Inquiry Model Assisted by Real Media to Improve the Understanding Concepts and Science Process Skills of Students. Jurnal Penelitian Pendidikan IPA, 7(1), 41-44. doi:https://doi.org/10.29303/jppipa.v7i1.473

Uce, M., \& Ceyhan, I. (2019). Misconception in chemistry education and practices to eliminate them: a literature analysis. Journal of Education and Training Studies, 7(3):202-208. Retrieved from: https://eric.ed.gov/?id=EJ1206967

Ulya, H. (2016). Profil kemampuan pemecahan masalah siswa bermotivasi belajar tinggi berdasarkan ideal problem solving. J. Konseling Gusjigang, 2(1): 90-96. doi: https:// doi.org/10.24176/jkg.v2i1.561 [Indonesian]

Wiqoyah, S, N. (2013). Peningkatan hasil belajar kimia materi senyawa hidrokarbon siswa SMAN 1 Kaliwungu dengan metode "TUBA ASYIK". Jurnal Inovasi Pendidikan Kimia, 7(2):1177-1188. [Indonesian]

Yakub, A.F., Mansyur, dan Sugiarti. (2018). Pengembangan media e-learning menggunakan edmodo berbasis smartphone untuk meningkatkan motivasi belajar peserta didik pada materi sistem koloid tingkat SMA. Chemistry Education Review (CER). 10(10):10-20. [Indonesian]

Yusrizal. (2016). Pengukuran dan Evaluasi Hasil dan Proses belajar. Yogyakarta: Pale Media Prima. [Indonesian] 